\title{
TRANSYLVANIA'S AND POLAND'S PARTICIPATION IN THE STRUGGLES BETWEEN THE MOLDAVIAN VOIVODE FAMILY, THE MOVILĂS, AND THE WALLACHIAN VOIVODE RADU ŞERBAN ${ }^{1}$
}

\author{
Sándor Papp \\ http://orcid.org/0000-0002-4740-4294 \\ University of Szeged (Hungary) \\ MTA-SZTE Research Group of the Ottoman Age (ELKH), Szeged (Hungary)
}

\begin{abstract}
The aim of this article is to analyse the relations of the three Ottoman vassal provinces (Transylvania, Moldavia and Wallachia) during the last years of the Long Turkish War (1591/93-1606). The provinces rebelled against the Ottomans at the beginning of the war. Then influenced by the policies of their dynasties or due to the military occupation of the neighbouring great powers such as the Habsburg monarchy, Poland and the Ottoman Empire, they changed the sides of the conflict. The Movilăs (or Movilă family) tried to govern two Romanian voivodships, Moldavia and Wallachia simultaneously. They had a good relation with the Ottomans and they supported rule of István Bocskai (r. 1604-1606), who rebelled against the Habsburgs in 1604 and was elected as the Prince of Transylvania and Hungary by the Hungarian rebels. The voivode of Wallachia, Radu Şerban
\end{abstract}

1 This essay based on the research project of the MTA-SZTE Research Group of the Ottoman Age. The research related to this paper was supported by the Ministry of Human Capacities (Emberi Erőforrások Minisztériuma) through the grant (code no. 20391-3/2018/FEKUSTRAT). This paper is written as a contribution of the Interdisciplinary Centre of Excellence, the Department of Medieval and Early Modern Hungarian History (Faculty of Humanities and Social Sciences) (University of Szeged), and the MTA-SZTE Research Group of the Ottoman Age. I want to thank the former and the recently Hungarian archival delegates István Fazekas and András Oross, who are responsible for the materials in the Austrian State Archives in Vienna (the Haus-, Hof- und Staatsarchiv and the Hofkammer Archiv). When I wrote my recent monography on the topic of the Bocskai Uprising, I have processed the material for the present study, to which I will quote below: S. Papp, Török szövetség - Habsburg kiegyezés. A Bocskai-felkelés történetéhez, Budapest 2014.

This article has already been published in part in Hungarian. The current paper is an enlarged, revised and, as well, updated version of the earlier published study. See the earlier article in Hungarian: S. Papp, "Erdély részvétele a moldvai vajdai család, a Movilăk és Radu şerban Havaslaföldi vajda küzdelmeiben. (1602-1606)," Acta Academiae Paedagogicae Agriensis Nova Series: Sectio Historiae 2017, no. 1, pp. $25-38$. 
(r. 1601, 1602-1610, 1611), who secretly allied himself with the Habsburgs, while simultaneously being recognised by the Ottoman side also endorsed him. The Prince of Moldavia, Ieremia Movilă (r. 1595-1606), tried to remove him from the Wallachian throne. He wanted to install his younger brother, Simion (r. 1600-1602 in Wallachia, r. 1606-1607 in Moldavia) - who had once held the title of the Prince of Wallachia - on the Wallachian throne after deposing of Radu Şerban. They formed an alliance with the Ottoman military dignitaries as well as with Bocskai to achieve their goal. Although this was an unsuccessful attempt, they strongly supported the Hungarian uprising. After the death of Ieremia Movilă, his sons tried to gain the power over Moldavia with Polish assistance. By contrast, the Hungarians gave military assistance to Simion against Ieremia's sons.

Keywords: Movilăs, Radu Şerban, István Bocskai, Gábor Bethlen, Transylvania, Poland, Ottoman vassals, Moldavia, Wallachia.

In the second phase of the Fifteen Years' or Long Turkish War (1591/93-1606), more and more significance was given to the attempt by the Sublime Porte to reacquire Transylvania, Moldavia and Wallachia, and by the Habsburg Court to retain rule over these three Christian principalities that had rebelled against the Ottoman rule at the outbreak of the war. Due to the hopelessness of the war, starting in 1597 the Princes of Transylvania took steps to return to the rule of the Sublime Porte. Important dates for these efforts were the years of $1599^{2}$ and 1601, when the Princes of Transylvania, Zsigmond Báthory (r. 1580-1601) and then András Báthory (r. 1599), signed treaties with the Sublime Porte, the objective of which, in addition to recognizing Ottoman authority, represented withdrawal from the war and a policy of a kind of neutrality. However, both efforts were unsuccessful due to the military intervention of the Habsburg Court and its ally Mihai Viteazul (r. 1593-1601 in Wallachia, r. 1600 in Moldavia and 1599-1600 governor in Transylvania). ${ }^{3}$

The anti-Habsburg rebels in Transylvania fled to Ottoman lands in 1602. Their leader was Mózes Székely (r. 1603 in Transylvania), who in a personally written letter asked the Grand Vizier Saturc1 Mehmed Pasha for the Sublime Porte to recognize him as the Prince of Transylvania and also to send one of the Romanian Voivodes with the unified forces of Moldavia and Wallachia to aid him. ${ }^{4}$ This request was difficult to fulfil at the time because of the battles for the throne of Wallachia that were ongoing. Radu Şerban had at this time driven out of power the Voivode of Wallachia Simion Movilă, brother of the Voivode of Moldavia Ieremia Movilă. ${ }^{5}$ Up until then Simion had occupied the office of Voivode of Wallachia

2 G. Kármán, "Báthori András ahdnáméja," Fons 2007, no. 14, pp. 339-348.; G. Kármán, "The 'Ahdname of Sultan Mehmed III to András Báthori, Prince of Transylvania" [in:] Contemporary Research in Turcology and Eurasian Studies: A Festschrift in Honor of Professor Tasin Gemil on the Occasion of His 70th Birthday, eds. S. Lascu, M. Fetisleam, Cluj-Napoca 2013, pp. 435-445.

3 S. Papp, Die Verleihungs-, Bekräftigungs- und Vertragsurkunden der Osmanen für Ungarn und Siebenbürgen. Eine quellenkritische Untersuchung, Wien 2003, pp. 109-125.

4 S. Papp, Török szövetség - Habsburg kiegyezés, pp. 55-57.

5 A. Veress, Documente privitoare la istoria Ardealului, Moldovei şi Ţării-Româneşsti. VII, Bucureşti 1934, no. 58, pp. 70-71. 
twice (between October 1600 and July 3, 1601, as well as between August 1601 and August 1602) with Polish backing.

Previously Radu Şerban had been waiting at the western border of Transylvania, in Beiuş (Belényes), for Giorgio Basta, commander-in-chief in Transylvania to provide him with military aid with which he could enter Wallachia. This was only possible following the renewed resignation of the Prince of Transylvania, Zsigmond Báthory. The invasion at the Turnu Roşu Pass (Vöröstorony szoros) was successful and by the beginning of August they had already taken the capital, Tîrgovişte. From there they made a brief attack on Moldavia, which was under the control of the Movilă family, and then the army returned to Tîrgovişte. It was from here that the report was made on September 2, 1602, in which the victorious Voivode Radu Şerban informed Emperor Rudolf II (as Holy Roman Emperor r. 1576-1612) about the events of the successful campaign and pleaded for more military support. ${ }^{6}$ Thus, it was impossible for the Movilă brothers to provide assistance to Mózes Székely in Transylvania. From the events up until now it is also apparent that the Moldavian Voivode dynasty, the Movilă family, had essentially constructed their conception of power on a peaceful Polish-Ottoman system of relationships. From 1602 Radu Şerban represented the interests of the Habsburg Empire in Wallachia, which included considering the Movilăs to be enemies. Subsequently to this, the objective of Moldavia's building up of diplomatic relationships was to reassert their control over Wallachia. In this effort it was possible to count on the Transylvanian opposition being organized against Habsburg rule as a prospective ally.

Mózes Székely's brief rule in Transylvania was ended by Radu Şerban when he moved against him with an armed force. During the losing battle near Brasov, Székely also died. The Transylvanian refugees again fled to Turkish lands, and already on August 29, 1603 they established contact with the Grand Vizier through the envoy Péter Széplaky, immediately requesting aid. ${ }^{7}$ Gábor Bethlen, the envoy of the Transylvanian refugees, travelled all the way to Belgrade, where he wrote to Cerrah Mehmed Pasha, asking for the soldiers' pay for the military force that remained with him. ${ }^{8}$ However, a rivalry for power developed amongst the refugees. According to the general opinion in the literature they were choosing between two leaders, with some wanting to see Boldizsár Szilvássy and others Gábor Bethlen at the head of the principality. The Sublime Porte supported the free election of the prince and issued a firman on this. ${ }^{9}$ Despite the fact that the voivode of Moldavia Ieremia Movilă

6 M. Stoy, "Radu Şerban, Fürst der Walachei 1602-1611, und die Habsburger. Eine Fallstudie," Südost-Forschungen 1995, no. 54, p. 63.

7 E. Veress, "Bethlen Gábor fejedelem ifjúsága. Erdélyi Múzeum," Új folyam 1914, no. 6, p. 317, no. 4; M. Horváth, "Magyar regesták a szepesi káptalan, jászai s leleszi conventek, Kassa és Sopron városok, s több magánosok levéltáraiból s gyüjteményéből 1228-1643," Magyar Történelmi Tár 1862, no. 11, p. 165 .

G. Kazinczy, Gr. Illésházy István nádor följegyzései 1592-1603 és Hídvégi Mikó Ferenc históriája 1594-1613 Bíró Sámuel folytatásával, Pest 1863, pp. 162-163; S. Papp, Török szövetség Habsburg kiegyezés, pp. 64-65.

9 Monumenta Comitalia Regni Transylvaniae. Erdélyi országgyülési emlékek. V., ed. S. Szilágyi, Budapest 1879, pp. 54-55; M. Horváth, Magyar regeszták, p. 162. 
also supported Szilvássy, ${ }^{10}$ the young Gábor Bethlen was elected their leader. Sándor Szilágyi, on the basis of the work of Farkas Bethlen, was of the opinion that the only reason why Szilvássy did not support Bethlen becoming prince was due to the maintenance of the free election of princes. However, a far more significant reason than this was that he wanted to acquire the honor of being prince. I have discovered well-founded evidence for this viewpoint that appears in the chronicles, and thus in the literature as well. The voivode of Moldavia Ieremia and Bektâş, the Beylerbeyi of Temesvár (present day Timişoara in Romania) prepared separate memoranda for the Sultan, in which they expressly requested that he name Szilvássy as the prince of Transylvania. ${ }^{11}$

Perhaps this division and the discord between the refugee Transylvanian estates were the reasons why Gábor Bethlen called upon István Bocskai, a magnate of eastern Hungary who was in conflict with the Habsburg court, to take up the throne of Transylvania. Bethlen was able to ensure Ottoman support for Bocskai in this. A few months after the outbreak of the revolt, the Hungarian rebellion against the Habsburgs that had erupted anew made contact with the Movilă family, who did everything they could to strengthen their prospective ally to rule Transylvania. ${ }^{12}$

Bocskai was the first who, without any election yet, used the customary title of Prince of Transylvania on December 12, 1604 in a letter written to the Transylvanian estates, even threatening the estates in case they did not renounce their loyalty to the emperor. It seems that at this time he had already agreed with the Voivode of Moldavia and the Pasha of Temesvár that he would receive military assistance from them. ${ }^{13}$

It was no accident that Bocskai suggested he could expect serious military support from Moldavia, since he had formed a close diplomatic relationship with the Movilă brothers, including a treaty of mutual protection and alliance. It can be presumed that István Bocskai initiated the contact in January 1605, when they planned the basis of the new system of relationships to be developed with the Ottoman state. ${ }^{14}$ When Bocskai sent a letter of reply to the Voivode Ieremia on March 25, 1605, he mentioned an alliance that they had planned for the long term between Moldavia, Wallachia and Transylvania. In particular Bocskai stressed that the Voivode had done much in the interest of the Székely people accepting him as their lord. The significance of this step must have been genuinely great, because the Sublime Porte praised Ieremia for making the Székely people loyal to Bocskai. ${ }^{15}$ The impact of this was felt when on

10 A. Veress, Documente VII., no. 125, p. 146.

11 Ibidem, p. 1934, p. 146, no. 125; Letter of Prince Ieremia in support of Boldizsár Szilvássy. Štátny Archiv-Pobočka Prešov, Fond Drugeth Humenné, Verejná činnost'. Župné vojenské záležitosti Inv. 316. I. č. 828/8. Mi I. 28.; Štátny Archiv-Pobočka Prešov, Fond Drugeth Humenné, Verejná činnost'. Župné vojenské záležitosti Inv. 316. I. č. 828/8. Mi I. 36. Letter of Bektâş Pasha in support of Boldizsár Szilvássy in Hungarian translation.

12 S. Papp, Török szövetség - Habsburg kiegyezés, pp. 57, 132-133.

13 K. Benda, I. Bocskai, Levelek, Bukarest-Budapest 1992, p. 258.

14 Iratok Bocskai István és kora történetéhez, ed. L. Nagy, Debrecen 2005, pp. 138-139, no. 40.

15 T. Gemil, Relaţiile Ţărilor Române cu Poarta Otomană în documente turceşti (1601-1712), Direcţia Generală a Arhivelor Statului din Republica Socialistă Români, Bucureşti 1984, pp. 103-104, no. 18; Arhivele Naţionale ale României (ANR), Direcţia Generală (DG), Bucureşti. Colecţia microfilme 
February 21, 1605 at Nyárádszereda (present day Miercurea Nirajului in Romania) the Székely people, and the Hungarian counties of Transylvania subsequently elected Bocskai as their prince. ${ }^{16}$

Ieremia requested that the legation of Bocskai do everything it could in the interest of his brother Simion's claim to the throne of Wallachia. From Bocskai's response it is clear that he wrote three times to inform Istanbul about this matter. He drafted a plan for both Movilă brothers to immediately prepare to move against Wallachia. To head the armies of Transylvania he named László Gyulaffy, who was prepared along with the Székely general János Petki ${ }^{17}$ to bring Simion Movilă in by force of arms to replace Radu Şerban..$^{18}$ On the same day the Prince also separately informed Simion about this, ${ }^{19}$ and in accordance with his promise immediately wrote to the Grand Vizier Lala Mehmed.

Bocskai considered the joint military intervention to be a done deal, which is rather surprising when we know that at this time the entourage of the Sultan and the Grand Vizier did not want to replace Radu Şerban. ${ }^{20}$

There could not have been irrefutable evidence against him in the hands of the Sublime Porte, or someone or a group was protecting him very well. The Sublime Porte's tactic of biding its time can be gathered from its commands with differing approaches. While they clearly put faith in the loyalty of the Wallachian people to the Sultan and they prohibited all military action against them,${ }^{21}$ there existed a mistrust towards the person of the voivode. Thus, in conjunction with the above, they encouraged the two Movilă brothers at the end of April, 1605 that if they served faithfully alongside Bocskai, their demand could be fulfilled. ${ }^{22}$ The mistrust was reinforced by the fact that Radu Şerban had not fulfilled the Sultan's order and had not set off in

Turcia, rola 107, c. 433; Başbakanlık Osmanlı Arşivi (in the following: BOA), (İstanbul) Mühimme defteri (MD), no. 77, p. 19, no. 103. Zilhicce 14, 1013. / May 5, 1605.

16 I. Horn, "Bocskai István fejedelem erdélyi politikusai" [in:] "Tudományos Konferencia a Bocskai István által vezetett Habsburg-ellenes rendi felkelés kitörésének 400. évfordulója alkalmából. 2004. december 6.," Studia Caroliensia 2006, no. 7/1, pp. 87-104; K. Juhász, "Bocskai István erdélyi országgyủlései” [in:] "Bocskai Istvántól Rákóczi Ferencig. Tanulmányok a kora újkori magyar történelemböl," Belvedere Meridionale 2012, no. 24 /3 pp. 6-15.

17 J. Balogh, I. Horn, "A hatalomépítés útjai: a homoródszentpáli Kornis család története," Századok 2008, no. 142/4, pp. 882-885; J. Balog h, Székelyföldi karrierek. Az udvarhelyszéki nemesség hatalomszerzési lehetöségei a 16-17. században, Budapest 2011.

18 K. Benda, I. Bocskai, Levelek, pp. 120-123, no. 51; K. Thaly, "Bocskay István leveleskönyve 1605. mart. 20.--april 29," Magyar Történeti Tár 1874, no. 19, pp. 73-75, no. 6; MNL OL MKA Lymbus Series II. 113. XXXII. fol. 14v-15v.

19 K. Benda, I. Bocskai, Levelek, pp. 123-124, no. 52; K. Thaly, "Bocskay István leveleskönyve," pp. 75-76, no. 7; MNL OL MKA Lymbus Series II. 113. XXXII. fol. 15v-16r.

${ }^{20}$ K. Benda, I. Bocskai, Levelek, pp. 124-127, no. 53; K. Thaly, "Bocskay István leveleskönyve," pp. 69-71, no. 4; MOL MKA Lymbus Series II. 113. XXXII. fol. 12v-13v.

${ }_{21}$ BOA MD, no. 77, p. 5, no. 71, Zilhicce 4, 1013. / April 23, 1605.

22 T. Gemil, Relaţiile Ţărilor Române cu Poarta Otomană în documente turceşti, pp. 101-103, no. 17; ANR, DG, București, Colecţia microfilme Turcia, rola 107. c. 426. The original of the document can be found in mühimme defter 77 containing the decisions of the Sultan's council. László Voloncs copied the entire contents of the volume for me in Istanbul, and I thank him for this. BOA MD, no. 77, p. 5 , no. 73 . 
person to Bocskai. If we consider that he probably also had information about the arrangements against him, then it is understandable that he remained where he was. If he was to move from the country, then it would have been much easier to implement his removal. At the same time, this step further increased the distrust towards him. The Sublime Porte altered its previous plan and allowed him to entrust a suitable individual to lead the Wallachian soldiers, instead of his doing so personally. At the same time, the voivode Simion saw to further duties, from which it could be gathered that if he did his job, then the reward would not be withheld. ${ }^{23}$ The parallel politics with the voivode and the claimant to the throne is quite interesting, because it is clear that Radu Şerban was in truth collaborating with the Habsburg military leadership. At least Giorgio Basta continued to consider him to be a man loyal to the emperor, and Giorgio Basta, the commander-in-chief of the Habsburgs in Hungary asked him for help against the rebels from Tokaj even in February 1605. ${ }^{24}$ Thus, at the time nobody was able to move Radu Şerban from his position, and - as I will touch upon below Bocskai would later be forced to enter an alliance with him.

In the meantime, in the spring of 1605 Bocskai set himself up in the role of a strong ally and vassal of the Sublime Porte, a position he wanted to use to further strengthen his standing through the signing of treaties. For this purpose, he sent a special legation to Istanbul. ${ }^{25}$ However, an important area of the negotiations also touched upon the power structure on the new north-western frontier of the Ottoman Empire. In addition to the instructions issued to the legation at the beginning, he sent more to the envoys that contained petitions of great significance. He requested that money be sent by the Sublime Porte for the maintenance of his armies and that the Sublime Porte get in with Sigismund III. Vasa (r. 1587-1632) King of Poland, so that he would not provide assistance to those on the side of the Emperor. He repeatedly petitioned for the removal of the Voivode Radu Şerban. We know from the reports of the envoys that the young Sultan Ahmed I (r. 1603-1617) guaranteed everything except for the removal of Radu Şerban. For that matter, at that time Radu Şerban's envoys were at the Sublime Porte and they were able to ensure the absolute loyalty to their lord. Also from the reports of Bocskai's envoys we know that the Voivode won the trust of the Grand Vizier Lala Mehmed. It was from this time that the Sultan's mandate came informing Radu that he had forbidden Simion's attack against Wallachia and ordered Radu to maintain a good relationship with Ieremia Movilă. From all of this it is apparent that in May 1605 the Sublime Porte made its decision in terms of the control of Wallachia: whatever steps Simion Movilă was to take in the interest of Bocskai and

23 BOA MD, no. 77, p. 14, no. 91-93.

24 Iratok Bocskai István és kora történetéhez, pp. 139-141, no. 45.

25 "Gyulafy Lestár följegyzései” [in:] Magyar történelmi évkönyvek és naplóka XVI-XVIII. századból. II., eds. S. Szilágyi, Gy. Tasnádi Nagy, F. Mencsik, J. Kluch, Budapest 1894, p. 38; M. Horváth, Magyar regesták, p. 170; S. Szilágyi, Erdélyország története tekintettel mivelödésére. II., Pest 1866, p. 78; L. Óváry, A Magyar Tudományos Akadémia Történelmi Bizottságának oklevélmásolatai. III., Budapest 1901, p. 30. 
Ottoman rule, he was not going to receive the Voivodeship as a reward ${ }^{26}$ As we will see, despite this the Movilăs continued to take steps against Radu Şerban. Serious sacrifices were made on the Transylvanian theatre of war and Kâdizâde Ali Pasha, the Beylerbeyi of Silistra also joined their structure of alliances.

At the conclusion of the Hungarian legation's negotiations in Istanbul, Ottoman forces under the leadership of Grand Vizier Lala Mehmed set off immediately towards Hungary. The military preparations against the Hungarian King (who was the Habsburg Emperor as well) have been passed down to us in the greatest detail in the chronicle of Abdülkâdir Efendi. ${ }^{27}$ However, since the author was originally a clerk for the artillery of the Sublime Porte, we cannot fault him for not mentioning Bocskai's delegation or the pledge. He was far more interested in the details of the war and its military and technical equipment. A detail of interest for military historians is how he presents the shooting drills of the Ottoman infantry, during which they tried to master the lines of continuous fire common in Europe, the so-called countermarch. ${ }^{28}$ The second known chronicler, İbrahim Peçevi (or Peçuyi), does not talk about the Istanbul plans, since he observed the unfolding of the events here in Hungary. ${ }^{29} \mathrm{We}$ also search in vain for the Istanbul plans related to the objectives of the campaign in the work of the later outstanding historian Haci Halife, otherwise known as Katib Çelebi. However, he did report reliably that the Grand Vizier Lala Mehmed Pasha set off for Hungary on May 21, 1605 from the Davud Pasha Field next to Istanbul. The chronicles and the western sources provide differing information on his arrival in Belgrade. According to the chronicler İbrahim Peçevi, he arrived at the beginning of July (according to information from Vienna, precisely on July $19^{30}$ ), and he continued his journey towards Buda from Zimony (present day Zemun or Земун in Serbia) Field (near to Belgrade) on July $20 .^{31}$

Besides the aforementioned chronicles, historians have hardly used sources in the Ottoman-Turkish language or those originating from the bodies of the Ottoman Empire that were issuing documents when discussing the military events of 1605 . It can be considered a fortunate circumstance that documents have survived in great

26 T. Gemil, Relatiile Ţărilor Române cu Poarta Otomană în documente turceşti, pp. 103-104, no.18; ANR, DG, Bucureşti, Colecţia microfilme Turcia, rola 107, c.433; BOA MD, no. 77, p. 19, no. 103.

${ }^{27}$ Topçular Kâtibi Abdulkâdir (Kadrî) efendi târihi. I. ed. Z. Yilmazer Doç. Dr., Türk Tarih Kurumu. Atatürk Kültür, Dil ve Tarih Yüksek Kurumu Türk Tarih Kurumu Yayınlari III. Dizi - Sayı 21', Ankara 2003, pp. 429-432; M. Köhbach, "Der Osmanische Historiker Topılar Kâtibi 'Abdü'lqâdir Efendi. Leben und Werk," Osmanlı Araştırmaları / The Journal of Ottoman Studies 1981, no. 2, pp. $75-96$.

28 Topçular Kâtibi, Târih I, p. 437.

29 I. Karácson, Török történetirók III, Magyar Tudományos Akadémia (Török-magyarkori történelmi emlékek. Írók.), Budapest 1916, pp. 177-190; İbrâhîm Peçevî, Târîh-i Peçevî. I-II, eds. F. Derin, V.Ç. Çabuk, İstanbul 1980.

30 M. Hatvani (Horváth), Magyar történelmi okmánytár a brüsseli országos levéltárból és a burgundi könyvtárból. IV., Pest 1859, p. 183. Archduke Matthias to Archduke Albert, Vienna, August 10, 1605. Cf. S.L. Tóth, A mezőkeresztesi csata és a tizenöt éves háború, Szeged 2000, 434, Footnote 21.

31 I. Karácson, Török történetirók. III., Budapest 1916, pp. 351-365; Kâtib Çelebi, Fezleke-i Kâtib Çelebi. I., İstanbul 1286, pp. 258-264. 
numbers in both Vienna and Istanbul that reflect the plans of the Ottoman side and its relationship with István Bocskai's movement. This is worthy of attention to the extent that a relatively large number of these were sent by the Grand Vizier Lala Mehmed to Bocskai. The collection is also worthy of attention from the aspect of Ottoman diplomatics and palaeography, since in general very few letters from a Grand Vizier have survived in archives. This is the case despite the fact that it was not uncommon for the influence of Grand Viziers on $17^{\text {th }}$-century events to be greater than the Sultan's Divan. This is particularly true when the Grand Vizier was forced into making independent decisions close to the battlefront as the commander of a military campaign (serdar). During the Long Turkish War, when several Grand Viziers fought on the western front, this mechanism could be considered natural, but we do not have as rich source data on other periods as we do for the Bocskai uprising. These letters are preserved in the Türkische Urkunden series at the Haus-, Hof- und Staatsarchiv in Vienna. Hardly any of the thirty-seven original letters I have uncovered have been used to this point in historiography, and Joseph Hammer-Purgstall completed a German translation of only one of them. ${ }^{32}$ At the same time, he listed the majority of them with a few words indicating their content in volume 9 of his history of the Ottoman Empire, where he indicated the sources for his work. ${ }^{33}$

The book of copies of decrees from the Sultan's Divan related to the campaign season of 1605-1606 is peculiar for the fact that a majority of these were created during the march of the Sultan's army to Hungary or at the theatre of war. The commands that were issued in the name of the Sultan by the serdars leading the Ottoman forces, in particular if they also happened to be the Grand Vizier as well, were copied into the "defter for important matters during military campaigns" (sefer mühimme defteri). In this case, a large proportion of the decrees did not come from the Divan in Istanbul, but from the state council called together during military campaigns. ${ }^{34}$ In the present case mühimme defter number 77 belongs to this category. ${ }^{35}$

The first entry of the volume gives cause for misunderstanding. In this, it is possible to see that it contains the commands recorded during the campaign season, some of which were created after having set off. The date on the letterhead is Muharram 1,

32 J. von Hammer-Purg sta11, Geschichte des Osmanischen Reiches. IV., Pest 1829, pp. 666-668.

33 Idem, Geschichte des Osmanischen Reiches. IX., Pest 1833, pp. 408-410.

34 On the typology and origins of mühimme defters, see: G. Dávid, P. Fodor, „Az ország ügye mindenek elött való”. A szultáni tanács Magyarországra vonatkozó rendeletei (1544-1545, 1552), Budapest 2005, (História Könyvtár. Okmánytárak 1. IX-XXXIV); M.S. Kütükoğlu, "Mühimme defterlerindeki muamele ve kayıdlar üzerine" [in:] Tarih boyunca paleografya ve diplomatik semineri, 30. Nisan-2. Mayls 1986, Bildiriler, İstanbul 1988, pp. 95-112; S. P a p p, Die Verleihungs-, Bekräftigungsund Vertragsurkunden der Osmanen, pp. 11-29. For the other outstanding important register of the Divan for mühimme defters, see: N.E. Kovács, “'Panaszok könyve.' Szempontok a sikájet defterik meghatározásához,” Keletkutatás 2011, Autumn, pp. 69-90.

${ }^{35}$ Caroline Finkel in her book on the Ottoman military administration during the Fifteen Years War also uses mühimme defter 77. In the chapter entitled Mobilisation she discusses the troops sent to Bocskai on pages 58-62. C. F i n k e 1, The Administration of Warfare: The Ottoman Military Campaigns in Hungary, 1593-1606. I-II. Wien 1988, VWGÖ. Beihefte zur Wiener Zeitschrift für die Kunde des Morgenlandes Band 14. 
1014 (May 19, 1605). ${ }^{36}$ Despite this, on the next page entries can be found related to preparations for the campaign with dates from February. Since it is known that the Grand Vizier returned from Belgrade to Istanbul at the beginning of February 1605, it does not seem impossible that the entries are testimonial proof of the organizational work that Lala Mehmed performed after arriving back to the capital. We first encounter Bocskai's name on the third page, the letter sent to him was handed over for delivery to Ahmed Müteferrika who had arrived from the frontier, and at the same time a chiaus named Mehmed was sent to Poland. Here also, in a margin note, it can be read that the sanjaks of Vulčitrin, Syrmia, Smederevo, Vidin, Nikopol and Kruševac were placed under the direction of the Beylerbeyi of Buda, Bektâş Pasha, to whom they gave the job of providing assistance to Bocskai. ${ }^{37}$

While advancing, preparations for the campaign were proceeding continuously, so they sent orders to the Pasha of Kanizsa, Sarhos İbrahim, to prepare for the joint military action. The Beylerbeyi of Kanizsa had to bring in the forces of the sanjaks of Mohács and Szigetvár. In the orders, they clearly stressed that the Beylerbeyi march to Gergely Némethi, who is referred to by the title of serdar in the text, so the initiative and the leadership even in Transdanubia was concentrated in the hands of the Hungarians. ${ }^{38}$ In order to provide sufficient forces in this area that was the frontier closest to the enemy, the Bosnian troops and even the previous Beylerbeyi of Bosnia were placed under the command of the Pasha of Kanizsa ${ }^{39}$ It is also clear that already in May they planned a serious invasion from here, the frontier area of Kanizsa, into the territory of the Habsburg hereditary lands. I would like to point out that during the campaign local knowledge counted for a great deal in the Ottoman army. The former Beylerbeyi of Kanizsa, Mustafa Pasha, who held the sanjak of Hercegovina (presumably as a temporary lower post) was ordered up with the cavalry from the ziamet and timar estates to protect the Požega frontier near his former post. ${ }^{40}$ At the same time, orders were given to the Bey of Požega that he should go to Kanizsa, because there were "some signs that his services were necessary due to some important matters." This order was also sent to the Bey of Hercegovina, and a copy was addressed to the Beylerbeyi of Bosnia, who also had to march to Kanizsa with his full forces. ${ }^{41}$ Alongside the commander-in-chief of the campaign, the Grand Vizier Lala Mehmed, military commands, bashbugs (baş ve buğ), were appointed at the head of forces operating separately from the main forces. For example, Sarhos İbrahim Pasha was given this title on July 5, when they invested him with the command of the Ottoman forces in Transdanubia. ${ }^{42}$

36 BOA MD, no. 77, p. 1.

37 BOA MD, no. 77, p. 3, no. 62-64, Şevvâl 4, 1013. / February 23, 1605.

38 "Mihâç ve Sigetvâr askeriyle müşârün ileyh tarafından ol cânibde olan Nîmete Gergeli nâm serdârına varub imdâd u muâvenet itmek emr edüb," BOA MD, no. 77, p. 49, no. 197, Muharram 15,1014. / May 23,1605.

39 BOA MD, no. 77, pp. 51-52.

40 BOA MD, no. 77, p. 53, document no. 206. Sefer 21, 1014. / July 8, 1605.

41 BOA MD, no. 77, p. 54, document no.. 208. Sefer 24, 1014. / July 11, 1605.

42 BOA MD, no. 77, p. 53, document no. 205. Sefer 18, 1014. / May 5, 1605. 
The original plan of the Grand Vizier was that he would set off back to Hungary from Istanbul at the earliest possible date. According to the command from the Sultan sent to his deputy, the kaymakam, (Kuyucu) Murâd Pasha who had remained in Belgrade, Lala Mehmed planned on departing between May 9 and 18, 1605 (mâh-i zî l-hiccenün evâhirinde). ${ }^{43}$ As we have seen, in reality due to the late arrival of Bocskai's delegation, the departure of the Ottoman army from Istanbul had to be delayed for a few weeks. In the official record of the Divan kept during the campaign, the first entry actually talking about aid to the Hungarian movement was addressed to the voivode of Moldavia, Ieremia Movilă, who was ordered to send three thousand good mounted cavalry and two thousand infantry with guns. The voivode of Wallachia, Radu Şerbân, received orders in parallel with this, and he had to send two thousand mounted cavalry and one thousand infantry to the Hungarians. ${ }^{44}$

The 1605 military campaign came to be of decisive significance on the part of the Ottoman Empire. This is shown, for example, by the text of the edict to the previous Pasha of Temesvár (Timişoara), now the Sanjakbeyi of Avlonya (Vlora), Ali (according to which the forces of the sanjak should arrive in Belgrade prior to the arrival of the Grand Vizier), "in this blessed year" in Hungary (Üngürüs) an enormous military campaign begins against the infidels. ${ }^{45}$ I find it important to emphasize a phrase such as this, although it appears in decrees at other times in similar cases, because the wording of the orders also accentuates the significance of the matter.

They determined several directions for the attack. Alongside the local forces in Hungary, whose commander was the Pasha of Eger, Sufi Sinân, the previous Pasha of Buda, the Beylerbeyi of Silistra at this time, Kâdizâde Ali Pasha had to set off, and had to hurry to the aid of István Bocskai with his troops the quickest. ${ }^{46}$ The above points genuinely do underscore the truth of Bocskai's letter that he wrote to the Sultan on April 8, according to which only Sufi Sinân Pasha was with him, and he could only hope that the others had set off towards him. ${ }^{47}$

As a matter of fact it should be highlighted that the Movilăs and the Pasha of Silistra supporting them neither knew of nor wanted to recognize the decision of the Sublime Porte, and even in August and September 1605, so three or four months after the issue of the Sultan's decree, they were organizing against Radu Şerban. In spite of this, István Bocskai understood that for the time being Radu Şerban the Voivode of Wallachia could not be removed from his position and he began to draw closer to him. The agreement between the Voivode of Wallachia and the Transylvanian delegation was established on August 5, 1605. The names of the Transylvanian envoys (Gábor Haller, János Kálnoky, Markus Schunkabonk and Michael Weiß) also show that the Saxons stood alongside Bocskai and they played an important role in the settlement. ${ }^{48}$ The promises of the Voivode were primarily restricted to military

\footnotetext{
43 BOA MD, no. 77, p. 9, document no. 80. Zilkade 1-10, 1014 / March 21-30, 1605.

44 BOA MD, no. 77, p. 3, document no. 67.

45 BOA MD, no. 77, p. 4, document no. 69. Zilkade 18, 1013 / April 7, 1605.

46 BOA MD, no. 77, p. 4, document no. 70.

47 K. B e n d a, I. B o c s k a i, Levelek, p. 151.

48 M. P h i 1 i p p i, Michael Weiß. Sein Leben und Wirken in Wort und Bild, Bukarest 1982, p. 46.
} 
assistance. The Transylvanians pledged to end the conflict that had developed during the time of Mihai Viteazul and create a good neighbourly relationship, to support Radu Şerban over Simion at the Sublime Porte, and if necessary, to provide refuge in Transylvania to him and his boyars. ${ }^{49}$

Despite the aforementioned, the alliance of the Movilăs and the Pasha of Silistra did not dissolve, two weeks after the Wallachian settlement Kâdizâde Ali Pasha still praised the Voivode Simion and requested that Bocskai intervene on his behalf. ${ }^{50}$ But by this time he must have known that the Voivode Simion's claims in Wallachia had been dropped both on the Turkish side and in the entourage of Bocskai. ${ }^{51}$ There is no doubt about this because the letter from Istanbul written by Vizier Haydar Pasha, who was in Brassov by October 9, and in this he happily recognized that following the agreement the Transylvanians also considered the Voivode Radu Şerban to be a loyal man of the Sublime Porte. ${ }^{52}$

Bocskai's ally Ieremia Movilă died on June 30, 1606 and skirmishes had begun to fill the throne. The Poles also intervened in the struggle. Although Miron Costin's very thorough chronicle only provided an unusually brief account of the events, and he even made an error of two years in the time of the voivode Ieremia's death, we do know from him that all of his sons were still too young to rule, so his brother Simion was chosen in their place. ${ }^{53}$ This fact is confirmed by the Grand Vizier Derviş Pasha's memorandum submitted to the Sultan, which made it clear that on the basis of the Polish-Ottoman peace treaty the son of Ieremia was genuinely the one who should have been installed, but the inhabitants of Moldavia indicated that the child was still a minor and was not capable of defending the country. Due to this, they requested that the Sultan name Ieremia's brother, Simion. ${ }^{54}$ On the basis of all of this it can

49 Szamosközy István történeti maradványai 1542-1608. IV, ed. S. Szilágyi, Budapest 1880, pp. 349-350; "Liber annalium raptim scriptus per Michaelem Veyss. Chroniken und Tagebücher. II.," ed. J. G r o s s [in:] Quellen zur Geschichte der Stadt Brassó. V., Brassó 1909, p. 184.

${ }^{50}$ Kâdizâde Ali Pasha, Beglerbeg of Silistra to István Bocskai, s.l., s.d. [Segesvár (?) (present day Sigişoara in Romania) around 20 August, 1605.] Österreichisches Staatsarchiv (ÖStA), Haus-, Hof- und Staatsarchiv (HHStA) Türkische Urkunden.

51 "Boğdân voyvodası olan Eremiya voyvoda ve karındaşı Simon voyvoda hazretinüzün cân u gönülden ve derûn-i dîlden muhibb-i sâdır-kâdîrdur. Uğurınuzda kendü nefisleri ve malleri ve askeri ile hizmetinüzden yüz çevirmezler her ne zemân lâzım oluna kendü askerinüz gibi hazırlardur. Eflâk voyvodalığı Simon muhibbinüze gerek azimetlü pâdişâhımuz hazretleri ve gerek sadr-i azam hazretleri vade buyurulmuşlardur.” Kâdizâde Ali Pasha, Beylerbeyi of Silistra to István Bocskai, s.l., s.d. [Segesvár? (Sigişoara) at the beginning of September, 1605.] ÖStA, HHStA, Türkische Urkunden.

52 J. Gross, Liber annalium, pp. 190-192.

53 M. Costin, "Grausame Zeiten in der Moldau. Die Moldauische Chronik des Miron Costin (15931661)," ed. A. Armbruster [in:] Rumänische Geschichtsschreiber 1, Graz-Wien-Köln 1980, p. 62.

54 T. Gemil, Relaţiile Ţărilor Române cu Poarta Otomană în documente turceşti, pp. 111-112, no. 23. The publisher determined the date in 1606. Since Ieremia died on 30 June and Murâd was named Grand Vizier on 21 June, and there was a need for correspondence between Moldavia and the Sublime Porte on the matter, I believe that it must have at the most been from the end of July or the beginning of August. Since Simion first wrote to the Transylvanians as voivode on 2 August, this further reinforces my theory (see: S. Szilágyi, A Rákóczyak kora Erdélyben. I., Pest 1868, p. 38). The term ahdname appears twice in the text of the telhis (proposal) of Dervish Pasha, and on the basis of this after Ieremia his son must be appointed to the Moldavian throne. At the time of the first printing, Mihai Maxim 
be established that Gáspár Bojti Veres and after him others retell the events imprecisely, according to which Bethlen had to provide assistance at the head of six thousand pikemen to the voivode Ieremia against rebels. Since Bethlen was still in Carei (Nagykároly) at the end of July 1606, after the Moldavian struggle for the throne had broken out, it can be presumed that his marching out of Transylvania occurred precisely due to the preparations for the Moldavian action. However, he could not have provided any assistance at all to Ieremia, since as we have seen he had already been dead for a month. Thus, without a doubt the Hungarian troops set off alongside Simion, and together with him came up against the royal Polish troops supporting Ieremia's sons. As a result of this, in September another delegation of protest arrived from Sigismund III. ${ }^{55}$ I do not think it is by chance that in parallel with these events arrangements commenced amongst the Szekélys that Radu Şerban and György Rácz initiated against Bocskai. ${ }^{56} \mathrm{I}$ would not be surprised if it was to come to light that behind Bethlen's Moldavian action, which according to Bojti Veres was only concluded after Bocskai's death, ${ }^{57}$ it would be possible to find support for Gábor Báthory's claim to the throne of Poland and the rebels against the king.

In conclusion it can be noted that the aforementioned events show a very close reciprocal influence between the two Romanian Voivodeships and the Principality of Transylvania, as well as the Hungarian rebels against the Habsburgs in this case. Through the evolution of the relationships of power, allied and enemy sides can be altered, although these individual interests had to be brought into harmony primarily with the greater powers in the area, the Habsburg and Ottoman Empires as well as the Kingdom of Poland.

interpreted it in such a way that during the time of Ieremia Movilă there was an Ottoman imperial pledge (ahdname) that dealt with the order of the inheritance of the throne of the voivode. That opinion of the Romanian historian would have been reinforced if an ahdname had been issued at the Sublime Porte when the voivode was named. M. M a x i m, Culegere de Texte Otomane. Bucureşti 1974, p. 96. (Telhis ... menţionînd existenţe unei „capitulaţii” (ahidnâme) acordate domnului Moldavei, Ieremia Movilă). However, in footnote 2 of the publication of Tahsin Gemil, an Ottoman-Polish international agreement dated 4 August, 1598 is discussed that should be understood as the ahdname in question. (T. Gemil, Relaţiile Ţărilor Române cu Poarta Otomană în documente turceşti, p. 112, footnote no. 2). It actually is included in the imperial pledge in question that as long as the voivode Ieremia is faithful to the Sublime Porte and performs his services he will be voivode, and after his death the position will go to his son. D. Kołodziejczyk, Ottoman-Polish Diplomatic Relations (15 th $-18^{\text {th }}$ Century): An Annotated Edition of 'Ahdnames and Other Documents, Boston-Köln 2000, p. 317.

55 "Tagebuch der Feldzüge des Regiements des Obristen Georg Freyherrn Ehrenreich beim Gran, und Eperjes von 27. Julii 1604 bis 26. Octorbis 1606 ausgeführet," ed. M.G. Kov achich [in:] Sammlung kleinerer, noch ungedruckter Stücke, in welcher gleichzeitige Schriftsteller einzelne Abschnitte der ungarischen Geschichte aufgezeichnet haben, Ofen 1805, p. 437. (The entry of the German commander in Prešov was from September 9).

56 Monumenta Comitalia Regni Transylvaniae. V., p. 313.

57 Bethlen Gábor emlékezete, ed. L. Makkai, Budapest 1980, p. 50. 


\section{BIBLIOGRAPHY}

\section{Primary Sources}

Arhivele Naţionale ale României (ANR), Direcţia Generală (DG), Bucureşti. Colecţia microfilme Turcia, rola 107.

Başbakanlık Osmanlı Arşivi (BOA), (İstanbul) Mühimme defteri (MD), no. 77.

Magyar Nemzeti Levéltár Országos Levéltár (MNL OL Magyar Kamara Archivuma (MKA)) Lymbus Series II. 113. XXXII.

Österreichisches Staatsarchiv (ÖStA), Haus-, Hof- und Staatsarchiv (HHStA) Türkische Urkunden.

Štátny Archiv - Pobočka Prešov, (Slovakia) Fond Drugeth Humenné, Verejná činnost'. Župné vojenské záležitosti.

\section{Primary Sources Published}

MNL OL MKA Lymbus Series II. 113. XXXII. fol. 14v-15v.

Benda K., Bocskai I., Levelek, Bukarest-Budapest 1992,

"Bethlen Gábor emlékezete," ed. Makkai L., Budapest 1980,

Costin M., "Grausame Zeiten in der Moldau. Die Moldauische Chronik des Miron Costin (1593-1661)," ed. A. Armbruster [in:] Rumänische Geschichtsschreiber 1, GrazWien-Köln 1980.

Dávid G., Fodor P., ,, Az ország ügye mindenek elött való”. A szultáni tanács Magyarországra vonatkozó rendeletei (1544-1545, 1552), Budapest 2005.

Gemil T., Relaţiile Ţărilor Române cu Poarta Otomană în documente turceşti (1601-1712), Bucureşti 1984.

“Gyulafy Lestár följegyzései” [in:] Magyar történelmi évkönyvek és naplók a XVI-XVIII. századból, II, eds. S. S z i lá g y i, Gy. Ta s ná N a g y, F. M e n c s i k, J. K 1 u c h, Budapest 1894.

Hatvani (Horváth) M., Magyar történelmi okmánytár a brüsseli országos levéltárból és a burgundi könyvtárból IV., Pest 1859.

Horváth M., "Magyar regesták a szepesi káptalan, jászai s leleszi conventek, Kassa és Sopron városok, s több magánosok levéltáraiból s gyüjteményéből 1228-1643,” Magyar Történelmi Tár 1862.

İbrâhîm Peçevî, Târîh-i Peçevî. I-II, eds. F. D e r i n, V.C. Ç a b u k, İstanbul 1980.

Iratok Bocskai István és kora történetéhez, ed. L. N a g y, Debrecen 2005.

Karácson I., Török történetírók III, Magyar Tudományos Akadémia. (Török-magyarkori történelmi emlékek. Írók.), Budapest 1916.

Kármán G., "Báthori András ahdnáméja," Fons 2007, no. 14, pp. 339-348.

Kármán G., "The 'Ahdname of Sultan Mehmed III to András Báthori, Prince of Transylvania" [in:] Contemporary Research in Turcology and Eurasian Studies: A Festschrift in Honor of Professor Tasin Gemil on the Occasion of His $70^{\text {th }}$ Birthday, eds. S. L a s c u, M. F e t i s 1 e a m, Cluj-Napoca 2013 pp. 435-445.

Kâtib Çelebi, Fezleke-i Kâtib Çelebi I., İstanbul 1286, pp. 258-264.

Kazinczy G., Gr. Illésházy István nádor följegyzései 1592-1603 és Hidvégi Mikó Ferenc históriája 1594-1613 Bíró Sámuel folytatásával, Pest 1863. 
Kołodziejczyk D., Ottoman-Polish Diplomatic Relations (15 th $18^{\text {th }}$ Century): An Annotated Edition of 'Ahdnames and Other Documents, Leiden-Boston-Köln 2000.

"Liber annalium raptim scriptus per Michaelem Veyss. Chroniken und Tagebücher. II.," ed. J. Gross [in:] Quellen zur Geschichte der Stadt Brassó. V., Brassó 1909.

Maxim M., Culegere de Texte Otomane, Bucureşti 1974.

Monumenta Comitalia Regni Transylvaniae. Erdélyi országgyülési emlékek, V., ed. S. S z i 1 á g y i, Budapest, 1879.

Óváry L., A Magyar Tudományos Akadémia Történelmi Bizottságának oklevélmásolatai III., Budapest 1901.

Papp S., Die Verleihungs-, Bekräftigungs- und Vertragsurkunden der Osmanen, für Ungarn und Siebenbürgen. Eine quellenkritische Untersuchung, Wien 2003.

Szamosközy István történeti maradványai 1542-1608 IV, ed. S. S z i 1 á g y i, Budapest 1880.

Szilágyi S., Erdélyország története tekintettel mivelödésére I-II., Pest 1866.

"Tagebuch der Feldzüge des Regiements des Obristen Georg Freyherrn Ehrenreich beim Gran, und Eperjes von 27. Julii 1604 bis 26. Octorbis 1606 ausgeführet," ed. M.G. Kovachich [in:] Sammlung kleinerer, noch ungedruckter Stücke, in welcher gleichzeitige Schriftsteller einzelne Abschnitte der ungarischen Geschichte aufgezeichnet haben, Gedruckt mit Königlichen Universitäts Schriften, Ofen 1805.

Thaly K., "Bocskay István leveleskönyve 1605. mart. 20.-april 29," Magyar Történeti Tár 1874, pp. 61-120.

Topçular Kâtibi Abdulkâdir (Kadrî) efendi târihi I, eds. Z. Y i 1 ma z e r D o ç. Dr., Türk Tarih Kurumu. Atatürk Kültür, Dil ve Tarih Yüksek Kurumu Türk Tarih Kurumu Yayınlari III. Dizi - Say1 21ª , Ankara 2003.

Veress A., Documente privitoare la istoria Ardealului, Moldovei şi Ţării-Româneşti VII, Bucureşti 1934, pp. 70-71, no. 58.

Veress E., "Bethlen Gábor fejedelem ifjúsága," Erdélyi Múzeum, Új folyam 1914, no. 6, no. 4 , pp. 285-312.

\section{Literature}

Balogh J., Székelyföldi karrierek. Az udvarhelyszéki nemesség hatalomszerzési lehetöségei a 16-17. században, Budapest 2011.

Balogh J., Horn I., "A hatalomépítés útjai: a homoródszentpáli Kornis család története," Századok 2008, no. 142/4, pp. 882-885.

Finkel C., The Administration of Warfare: The Ottoman Military Campaigns in Hungary, 1593-1606, I-II. Wien, 1988, VWGÖ. Beihefte zur Wiener Zeitschrift für die Kunde des Morgenlandes, Band 14.

Hammer-Purgstall J. von, Geschichte des Osmanischen Reiches. IV., Pest 1829, pp. 666668.

Hammer-Purgstall J. von, Geschichte des Osmanischen Reiches. IX., Pest 1833, pp. 408410.

Horn I., "Bocskai István fejedelem erdélyi politikusai” [in:] "Tudományos Konferencia a Bocskai István által vezetett Habsburg-ellenes rendi felkelés kitörésének 400. évfordulója alkalmából, 2004. december 6.," Studia Caroliensia 2006, no. 7/1, pp. 87-104.

Juhász K., "Bocskai István erdélyi országgyülései” [in:] "Bocskai Istvántól Rákóczi Ferencig. Tanulmányok a kora újkori magyar történelemböl," Belvedere Meridionale 2012, no. $24 / 3$ pp. $6-15$. 
Köhbach M., "Der Osmanische Historiker Topılar Kâtibi 'Abdü'l-qâdir Efendi. Leben und Werk," Osmanlı Araştırmaları / The Journal of Ottoman Studies 1981, no. 2, pp. 75-96.

Kovács N.E., "'Panaszok könyve.' Szempontok a sikájet defterik meghatározásához,” Keletkutatás 2011, Autumn, pp. 69-90.

Kütükoğlu M.S., "Mühimme defterlerindeki muamele ve kayıdlar üzerine" [in:] Tarih boyunca paleografya ve diplomatik semineri, 30. Nisan-2. Mayls 1986, Bildiriler, İstanbul 1988.

Papp S., Die Verleihungs-, Bekräftigungs- und Vertragsurkunden der Osmanen, für Ungarn und Siebenbürgen. Eine quellenkritische Untersuchung, Wien 2003.

Papp S., "Erdély részvétele a moldvai vajdai család, a Movilăk és Radu şerban Havaslaföldi vajda küzdelmeiben (1602-1606)," Acta Academiae Paedagogicae Agriensis Nova Series: Sectio Historiae 2017, no. 1, pp. 25-38.

Papp S., Török szövetség - Habsburg kiegyezés. A Bocskai-felkelés történetéhez, Budapest 2014.

Philippi M., Michael Weiß. Sein Leben und Wirken in Wort und Bild, Bukarest 1982.

Stoy M., "Radu Şerban, Fürst der Walachei 1602-1611, und die Habsburger. Eine Fallstudie," Südost-Forschungen 1995, no. 54, pp. 49-103.

Szilágyi S., A Rákóczyak kora Erdélyben I., Pest 1868.

Tóth S.L., A mezőkeresztesi csata és a tizenöt éves háború, Szeged 2000. 